\title{
Innovative Approach to Sustainable Mobility and Transport Through Big Data From ICT - Pilot Study in Cracow, Poland
}

\author{
Lidia Zakowska $^{1 *}$, and Zofia Bryniarska ${ }^{1}$ \\ ${ }^{1}$ Cracow University of Technology, 24 Warszawska str., Krakow, 31-155, Poland
}

\begin{abstract}
New challenges of urban transport are connected to sustainability, the growing urban population globally, life quality and quality of urban environment, reduction of pollution and energy consumption. Sustainable urban mobility is no more dependent only on passenger transport efficiency, but also on transport accessibility of commuting services, acceptable level of comfort, safety and security of urban public transport and many more. Although a huge amount of data are available from modern communication services, the question of how to use those big data efficiently to improve urban mobility is unknown. Positive changes of mobility attitudes and travel behavior of citizens are going slowly, which means that personal motivation do not follow big data availability. This motivation is dependent on quality of public transport offer and services, among which information services are suspected to play a crucial role. Modern ICT methods of transport information delivery are based on Internet and social media, which through commonly used mobile devices are available at every stage of journey. In this article authors try, based on the pilot survey, to check how young Krakow citizens use social media in every day travels and commuting. The overall goal of the author's study is to answer the question: how to use big data coming from ICT in order to upgrade urban transport sustainability.
\end{abstract}

\section{Introduction}

Number of people living in urban areas is growing every year. According to the forecast by the United Nations it is expected that in 2050 more than $70 \%$ of the world population will be living in cities [13]. Cities and urban areas get extended forming their structure to allow resident to find proper circumstances for living, working, educating, business and social life. All this daily duties and needs force people to travel and to change places. They have to move inside the city, but also between cities and villages in the immediate area, around the country and in the world. People, society and economy become on one hand transportation dependent, but on the other hand, they are more and more aware of the threads generated by transport. The problem of making transport sustainable have been discussed at local, European and global level. The development of sustainable mobility and

* Corresponding author: 1zakowsk@pk.edu.pl 
transport, which will provide efficient, safe, effective transportation options and, at the same time, ensure economic development of urban areas and access to them, improvement of life quality and environmental protection and are widely formulated in European documents. The solutions, proposed among others in White Paper (2001) [24] and Green Paper (2007) [9], are perceived in a more accessible, intelligent, safe and reliable urban transport, where the share of walking, cycling and urban public transport will increase. Moreover, the vision of a competitive and sustainable transport system and the need to support integrated mobility while achieving the target of reducing emissions by $60 \%$ has been highlighted in the White Paper (2011) [25].

This challenges relay on how to make services more efficient and competitive, reduce congestion, decrease dependence on automobile, number of single occupant vehicle travels and improve communities and living conditions [12, 26, 27, 4, 5]. It is generally understood that better modal split, with high share of public transport can bring a relief and help cities to became more movable. Under this context, urban public transport is obliged to not only retain existing users but to attract new users. One of the way to achieve this goal is public transport integration and innovation [29].

The idea of integration is about the pursuit of synergy and removal of barriers [14], creation of tools for assuring continuity of journey from door to door [10]. Integration is a process carried out within a local (urban) transport system in conjunction with the systems of extended range, including combination of movements by various modes of transport [6] and combined impact on different levels: spatial, constructional, organizational, economic, financial as well as informational [18]. The level of information availability at any stage of travel is crucial.

In the article authors try, based on the survey, to answer the question whether young Krakow citizens use and appreciate, or are addicted to, social media in every day travels and commuting. The main question is how to use such a big data coming from ICT to upgrade urban transport sustainability.

\section{Literature review}

Numerous studies explore various aspects of travel experience. Some researchers used to compare the level of passengers' preferences with assessment of passenger's satisfaction, formulating the existing gap [19] and showing public transport quality features that should be improved. Many other studies [29, 30] showed that transport information is one of that features, that significantly improve user satisfaction and can increase public transit ridership.

It is difficult to overestimate the role of travel information, not only static but real-time transit information, in particular [21]. Traditionally, transport operators have offered to passengers static transportation timetables and online journey planners based on static data or on its real-time counterparts. Even static information are useful for passengers and help them overcome problems of uncertainty, unpredictability and anxiety before, during and after their by means of public transport [11]. The main role of passenger information is to make it easier for travelers to access services offered by public transport organizers and to increase the use these services. The information system must be legible and tailored to all potential public transport users [3]. Planning a journey with the use of the available (traditional or modern) sources of information about the routes and timetables of communication lines passenger easily decide if he can make his move by means of public transport, at what time and at what cost. This information allows the user to largely reduce uncertainty and discomfort due to the risk of not achieving the destination on time. Information available during travel is especially appreciated by unfamiliar travelers [17], although they have a great potential to facilitate travel for habitual ones as well. This kind 
of information refers to wayfinding, transferring and ticketing and can reduce stress and confusion. Negative experiences during first travel are considered by many to be a great barrier to mode shift [22]. The first trip therefore represent a potential window of transition from habitual travel to establishment a new travel behaviors. Public transport services that cater for unfamiliar users may also encourage car users to make a mode shift to transit [16]. Last stage of passenger travel demands information on how to reach his ultimate destination (directional signs with important places), possibility of return journey, stop environment (correctly marked exit roads, city map).

Introduction of interactive information systems with real-time passenger information is a promising solution. The proliferation of mobile Wi-Fi and the increasing prevalence of smartphones shift the focus strongly on mobile passenger information systems realized as smartphones app [15]. This way, on the one hand, passengers are offered the opportunity of easy and instant information access [20] and on the other hand they become addicted to these facilitative applications [15]. Crucial for the success of these services are their quality in terms of comprehensiveness and completeness of provided information and usability for passengers. The constant improvement of their functionalities and monitoring user preferences helps to meet passengers' expectations [1, 2]. Additional functionalities embrace among others: pedestrian navigation in multi-modal routing service [28], check availability of bikes at the corresponding station [23], current passenger position to continuously guide them during their trip by providing highly contextual and highly personalized information [23].

\section{Survey and its result}

\subsection{Method, participant and procedure}

Survey questionnaire was elaborated as a pilot one within Cost Action TU1305 - Social Networks and Travel Behavior. It consists of over 40 questions referring, most of all, to social media, their understanding and usage among young generation and a few of them to characterize respondent himself (e.g. his age, gender, role at the university). The aim of this pre-test made in Cracow survey is to learn what is the impact of Information and Communication Technologies on social activities and travel.

The poll was carried out in written among 82 students of Cracow University of Technology who studied at Faculty of Civil Engineering. The responding group (82 students), aged $20-25$, both female (56.8\%) and male (46.2\%), in majority of over $90 \%$ possessed a driving license and also had a public transport pass.

The data were collected in December 2016, than statistically analyzed and evaluated.

\subsection{Results}

The first important evaluation was related to the current state of what kind of ICT and electronic devices students have and how frequently do they use them. Among seven different ICT devices, two of them occurred to be possessed by majority of students and also very frequently used, namely laptops and smartphones (Figure 1). Another devices, like desktops, tablets, cellphones and game consoles are neither possessed nor frequently used in this group of respondents in Poland. This result suggests that engineering students are less interested in ICT devices which are produced for fun and entertainment, but rather use multifunctional laptops and smartphones everyday.

Students were also asked to rank by order of importance four transport modes which they used during the week before the survey, namely: walking, biking, car (as a driver or a 
passenger) and public transport (including combination of car, bus, tram, train, taxi etc.). The results are presented in Figure 2, where the difference between weekdays and weekends is visible, showing increased use of car during weekend, while during weekdays the public transport use is predominant $(86,4 \%$ of all declared trips were made using public transport).

Next part of analysis concerns reasons which most often influence the Polish students use of web/apps before their travel to the activity. The results of this analysis are summarized in Figure 3. Most often (every time or almost all times and the majority of times) students use web/apps to search for PT schedules (over 75\%) and to check for the best mode or route to go (57\%). Less frequent (only sometimes or half of times or never) students declared they use ICT before travel to keep updated about travel conditions, and hardly ever to buy ticket (over $40 \%$ declared they never do, which is explained with their declared possession of PT travel pass. Students are also not very often using ICT to call taxi and to reserve a shared car (less than 5\% always do, while over $40 \%$ never).

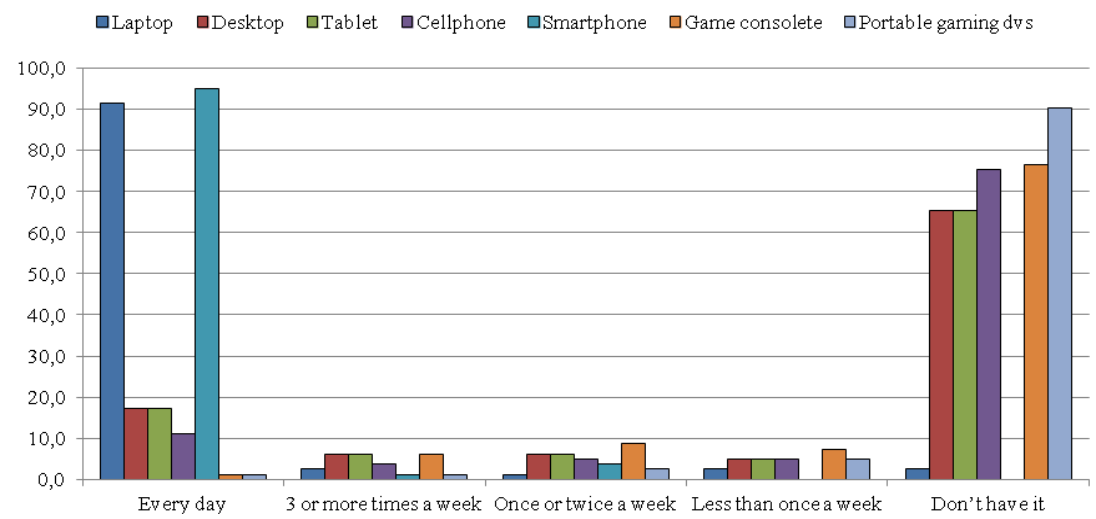

Fig. 1. Percentage of Polish students response on the question: What ICT and electronic devices do you have and how frequently do you use them?

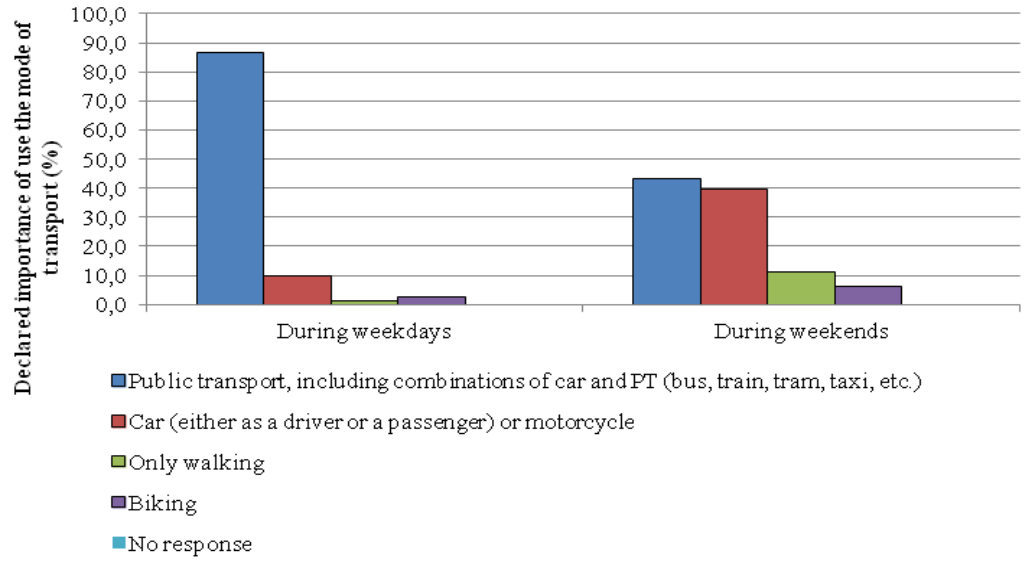

Fig. 2. Ranks by order of importance (\%) of the transport options used by students to travel to social activities during weekdays and during weekends. 


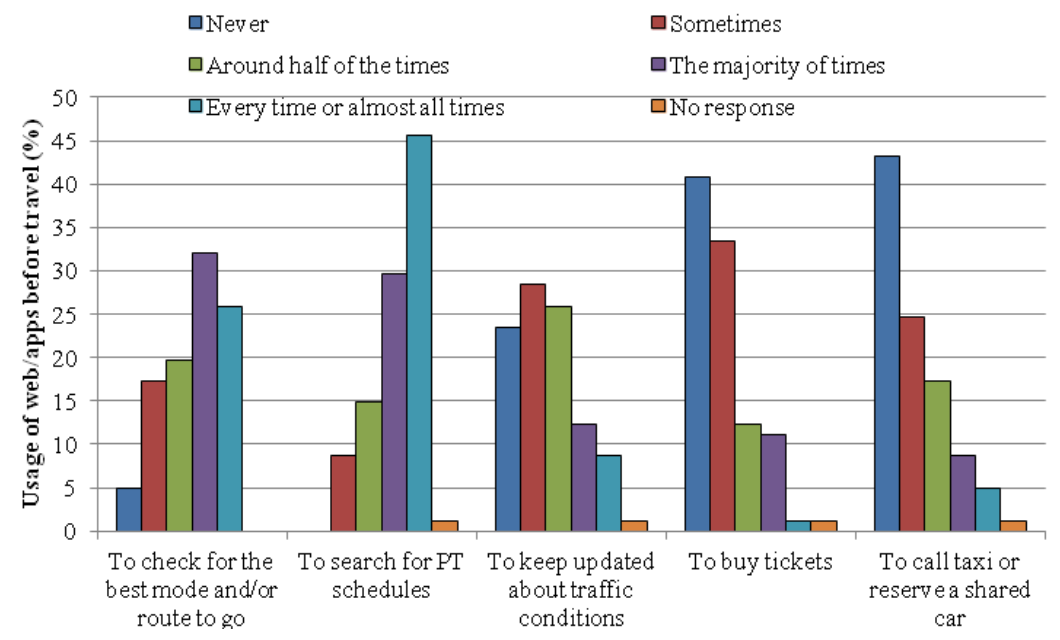

Fig. 3. Responses (\%) to: How well do the following statements describe your use of ICT (mail, sms, telephone calls, chat, social media, internet, smartphone apps) in your social activities during the last week - BEFORE TRAVEL TO THE ACTIVITY.

Another interesting results reviled the answers to the question why Polish students use ICT (mail, sms, telephone calls, chat, social media, internet, smartphone apps) in their social activities during the trip (see Figure 4). There are several reasons to use ICT during the trip, also there are different frequencies of using ICT for each purpose. The most often reason is to keep friends posted, while making phone-calls and posting on social networks received similar ranks, showing the largest group (34,6\%) of those who declared never doing it. This results show that students are mainly using ICT during their trips to contact their social group with short messages, not especially related to the trip they do.



Fig. 4. Responses (\%) to: How well do the following statements describe your use of ICT (mail, sms, telephone calls, chat, social media, internet, smartphone apps) in your social activities during the last week - DURING THE TRIP. 


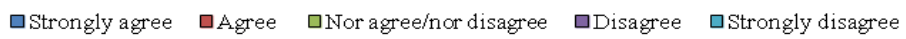

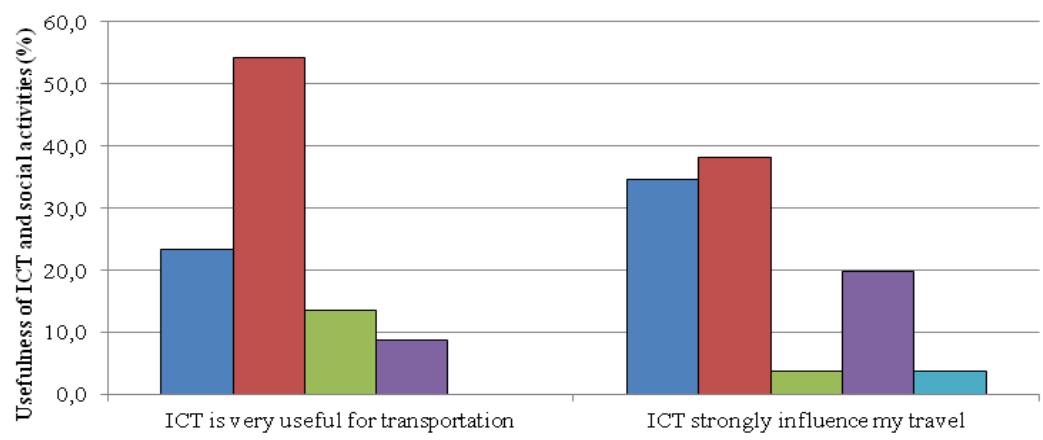

Fig. 5. Students opinion on how useful are ICT for transportation and how much ICT influence their travels to social activities (\% of agreement to usefulness).

The last analysis presented in this study relates to the student's evaluation on how useful for transportation purposes are ICT and how much do they think ICT influence travels to social activities. Those results are presented in Figure 5.

Nearly $80 \%$ of Polish students confirmed usefulness of ICT for transportation (strongly agree and agree that ICT is useful), while only less than $10 \%$ of respondents think that it is not useful, which is shown in the left part of Figure 5. Also the assessment of ICT influence on personal trips (presented on the right side of Fig. 5) met high agreement of majority of students. $34,6 \%$ of students strongly agree with the statement that ICT strongly influence their travels to social activities and another group of $38,3 \%$ agree with it. This result confirm the hypothesis, that ICT use is very popular among young people and that it influence their transport behavior.

\section{Conclusions}

While we are facing the rapid growth of ICT based methods and ways of providing information, and at the same time the availability of all mobile devices, Internet, social media is spreading from day to day, there is still no systematic knowledge on how to use efficiently those information systems to upgrade the quality of urban transport and mobility in our cities. This study was designed and conducted in order to collect the first researchbased know-how on how big data related to public transport are used by young citizens and how this use may upgrade the quality of urban transport. The results presented in this article are based on the pilot survey completed by students in Krakow, Poland. The general research aim was to answer the question how to use such a big data coming from ICT in order to upgrade urban transport sustainability.

The first research question was to check whether young Krakow citizens use and appreciate, or whether they are addicted to the use of social media in every day travels and commuting. As majority of students have and also very frequently use laptops and smartphones, it is easy to conclude that those ICT devices should be developed toward wide implementation of transport information.

The second interesting result from this study is related to classification of four transport modes which young people use during the weekdays and during weekends in urban area of Krakow, namely: walking, biking, car (as a driver or a passenger) and public transport (including combination of car, bus, tram, train, taxi etc.). The analysis showed that public transport is essential in urban mobility of students. It may be concluded that this group of 
transport users will be open to the wide use of modern ICT based information, forcing development of innovating passenger information.

Another conclusion from this study is related to the future of social media and ICT use in relation to travel behavior. The study showed that there is a wide range of reasons and goals for young generation to use innovating passenger information before and during their travel. This conclusion is very promising for the future of ICT and big data involvement in upgrading quality of urban mobility, although does not explain how to use the big data efficiently.

Further study is needed in order to find out what should be done in the nearest future to develop such an innovating passenger information that will lead to building sustainable urban transport system through the user's behavior change.

In current research it is being underlined that digital/electronic devices and interactive services create a unique, enjoyable and meaningful user experience [8; 31], and are changing image public transportation service as modern and focused on fulfilment of passengers' satisfaction [15]. Passenger are usually open to new, modern and innovative services and involve themselves in spreading this solutions by sharing information on all advantages and improvements in their private life via social media. Among the young generation, the car and its ownership cease to be trendy and determinant of ownership [7]. They prefer to travel by means of public transport and stay connected via social media with their friends and acquaintances.

This work was made in frame of the L3/236/2016/DS. Research at Politechnika Krakowska as a research Partner of the COST Action TU1305 in 2015-2017.The survey was developed and conducted as a pilot study in Krakow, Poland, based on the pilot questionnaire of the running research of the TU1305 COST project "Social Networks and Travel Behavior".

\section{References}

1. S. Beul-Leusmann, C. Samsel, M. Wiederhold, K-H. Krempels, E-M. Jakobs, M. Ziefle, Usability Evaluation of Mobile Passenger Information Systems, In: Design, User Experience, and Usability. Theories, Methods, and Tools for Designing the User Experience, Third International Conference, DUXU 2014, Held as Part of HCI International 2014, Heraklion, Crete, Greece, June 22-27, Proceedings, Part I. (2014)

2. P. Bielanski, Analysis of the Use of Tools Designed to Plan a Trip by Public Transport among the Users of the Internet, in Polish: Analiza wykorzystania narzędzi służących do planowania podróży transportem miejskim przez użytkowników Internetu, unpublished work Faculty of Civil Engineering, Cracow University of Technology (2016)

3. K. Bojda, Rola informacji pasażerskiej w miejskim transporcie zbiorowym, Transport Miejski i Regionalny, 9, pp. 24-29 (2011)

4. Z. Bryniarska, Competition Tools in Passenger Transport in Urban Areas, in Contemporary Challenges of Transport Systems and Traffic Engineering, ISBN 978-3319-43984-6, Seria: Lecture Notes in Networks and Systems 2 (ISSN: 2367-3370) 13th Scientific and Technical Conference "Transport Systems. Theory and Practice 2016 Katowice, Poland, Springer International Publishing Switzerland, pp. 3-13 (2016)

5. E. Burzec-Burzyńska, Z. Kłos, Wykorzystanie środków informacji pasażerskiej w komunikacji miejskiej na przyktadzie polskich miast, Zeszyty Naukowe Uniwersytetu Szczecińskiego, 680 (2012)

6. G. Dydkowski, Integracja transportu miejskiego, Wydawnictwo Akademii Ekonomicznej w Katowicach, Katowice (2009) 
7. A. Flausch, It's all about transformation, innovation and communication, Public Transport International UITP, 1, pp. 4-6 (2013)

8. M. Foth, R. Schroeter, Enhancing the Experience of Public Transport Users with Urban Screens and Mobile Applications. In: Proceedings of the 14th International Academic MindTrek Conference, pp. 33-40. ACM, New York (2010)

9. Green Paper 2007. Towards a New Culture for Urban Mobility, COM(2007) 551, Brussel (2007)

10. M. Janic, A. Reggiani, Integrated Transport Systems in European Union: An Overview of Some Recent Developments, Transport Reviews, vol. 21, 4, pp. 469-497 (2001)

11. R. Kedzior, Z. Bryniarska, Informacja pasażerska w publicznym transporcie zbiorowym, Transport Miejski i Regionalny, 6, pp. 26-33 (2015)

12. C.A. Klöckner, T. Friedrichsmeier, A Multi-level Approach to Travel Model Choice How Person Characteristics and Situation Specific Apects Determine Car Use in a Student Sample.Transportation Research Part F:Traffic Psychology and Behaviour 14(4), pp. 261-277 (2011)

13. W. Lerner, F-J. Van Audenhove, The Future of Urban Mobility: Towards Networked, Mulimodal Cities in 2050, Public Transport International, 2, pp.14-18 (2012)

14. A.D. May, C. Kelly, and S. Shepherd, The Principals of Integration in Urban Transport Strategies. Transport Policy 13(4), pp. 319-327 (2006)

15. A. Rakotonirainy, T. D. Camacho, M. Foth, Pervasive Technology and Public Transport: Opportunities Beyond Telematics, IEEE Pervasive Computing, vol. 12, 18 25, Jan.-Mar. 2013, doi:10.1109/MPRV.2012.61 (2012)

16. L. Schmitt, G. Currie, A. Delbosc, Measuring the Impact of Unfamiliar Transit Travel Using a University Access Survey, Transport Policy 30 pp. 301-307, http://dx.doi.org/10.1016/j.tranpol.2013.09.003. (2013)

17. L. Schmitt, G. Currie, A. Delbosc,. Lost in Transit? Unfamiliar Public Transport Travel Explored Using a Journey Planner Web Survey? Transportation 42, pp. 101122, DOI 10.1007/s11116-014-9529-2. (2015)

18. K. Solecka, Integration of Public Transport in Polish and EU Documents and Examples of Solutions for Integration of Public Transport in Poland and in the World, Transport Problems, Vol. 6, 4 (2011)

19. W. Starowicz, Kształtowanie jakości usług przewozowych w miejskim transporcie zbiorowym. Wydawnictwo Uniwersytetu Szczecińskiego, Szczecin (2001)

20. C. Sungur, I. Babaoglu, A. Sungur, Smart Bus Station-Passenger Information System, In: Proceedings of the 2nd International Conference on Information Science and Control Engineering, IEEE, DOI 10.1109/ICISCE.2015.209 (2015)

21. L. Tang, P. Thakuriah, Ridership Effects of Real-time Bus Information System: A case study in the City of Chicago, Transportation Research Part C: 22, pp.146-161, doi:10.1016/j.trc.2012.01.001 (2012)

22. J. Thøgersen, Promoting Public Transport as a Subscription Service: Effects of a Free Month Travel Card. Transp. Policy, 16(6), pp. 335-343. doi:10.1016/j.tranpol.2009.10.008 (2009)

23. N. Volanschi, Towards Smart and Sustainable Multi-modal Public Transports Based on a Participatory Ecosystem. Workshop on Smart and Sustainable City (WSSC'16), Jul 2016, Toulouse, France. <https://www.irit.fr/ Georges.Da-Costa/wssc/>. $<$ hal$01318341>(2016)$ 
24. White Paper 2001. European Transport Policy for 2010. Time to Decide. COM(2001) 370, Brief Presentation, Brussel.

25. White Paper 2011. Roadmap to a Single European Transport Area - Towards a Competitive and Resource Efficient Transport System, COM (2011) 144 final, Brussels.

26. S. Wirtz, E.-M. Jakobs, S. Beul, Passenger Information Systems in Media Networks Patterns, Preferences, Prototypes. In: Proceedings of the IEEE International Professional Communication Conference, pp. 131-137. IEEE Press, New York (2010)

27. O. Wyszomirski, et. all. Transport miejski. Ekonomika i organizacja, Wydawnictwo Uniwersytetu Gdańskiego, Gdańsk, pp. 243-252 (2008)

28. H. Yu, F. Lu, Advanced Multi-Modal Routing Approach for Pedestrians. In: Proceedings of the 2nd International Conference on Consumer Electronics, Communications and Networks (CECNet), pp. 2349-2352. IEEE Press, New York (2012)

29. L. Zakowska, Wizualizacja, modelowanie i analizowanie przestrzeni transportu miejskiego w aspekcie estetycznym (2014)

30. L. Zakowska, D. Kubek, P. Więcek, Advanced Transport Analysis and Traffic Control Methods in Intelligent Transportation Systems, / ed. by Stanisław Gaca, Wydawnictwo Politechnika Krakowska, Seria: Inżynieria Lądowa, Monografia 483, ISSN 0860097X, 229-247 (2015)

31. www.tu1305.eu - public documents of the COST Action TU1305 project. 